\title{
Implementasi Pembelajaran Daring di Masa Pandemi Covid-19
}

\section{Online Learning Implementation in The Covid-19 Pandemic}

\author{
Bagus Cahyanto ${ }^{1}$, Masyinta Maghfirah ${ }^{2}$, Nur Hamidah ${ }^{3}$ \\ Program Studi Pendidikan Guru Madrasah Ibtidaiyah, Fakultas Agama Islam \\ Universitas Islam Malang \\ e-mail: ${ }^{1}$ baguscahyanto@unisma.ac.id
}

\begin{abstract}
Abstrak: Pandemi Covid-19 membawa dampak besar terhadap praktik pembelajaran yang beralih menggunakan metode online. Penelitian ini bertujuan untuk mendeskripsikan pelaksanaan, kendala, dan strategi sekolah dalam mengatasi kendala pembelajaran daring di kelas III SD Brawijaya Smart School. Penelitian ini menggunakan pendekatan kualitatif deskriptif dengan teknik wawancara, observasi, dan dokumentasi untuk pengumpulan data. Hasil penelitian menunjukkan bahwa pembelajaran daring dilaksanakan dengan memanfaatkan platform dan aplikasi berbasis online yaitu Microsoft Teams. Guru melakukan virtual meeting di awal pembelajaran untuk menyampaikan materi, kemudian memanfaatkan Youtube dan Whatsapp untuk penguatan materi, penugasan, dan penilaian. Kendala-kendala yang muncul diantaranya (a) tidak semua siswa menggunakan handphone secara mandiri, (b) adanya orang tua yang belum mampu mendampingi belajar siswa dengan maksimal, (c) jaringan internet yang kurang stabil, dan (d) terbatasnya waktu yang digunakan dalam pembelajaran daring, sehingga guru kesulitan untuk memantau sikap siswa saat belajar dirumah. Langkah strategis yang sudah dilakukan sekolah yaitu (a) peningkatan kapasitas guru dalam penguasaan teknologi digital, (b) penggunaan media pembelajaran daring yang lebih variatif dan interaktif untuk mengurangi kebosanan belajar siswa, (c) mengupayakan peyampaian materi kepada siswa sehari sebelum pembelajaran, dan (d) melibatkan orang tua siswa secara intensif untuk komunikasi dan koordinasi dalam upaya membantu mengawasi dan mendampingi belajar siswa di rumah.
\end{abstract}

Kata Kunci: pembelajaran online, pandemi covid-19, sekolah dasar

Abstract: The Covid-19 pandemic has impacted the learning practices to shifted using online methods. This study aims to describe the implementation, the obstacles, and the strategy of online learning to overcome learning constraints at the third grade of Brawijaya Smart School Elementary School. This research used a descriptive qualitative approach with an interview, observation, and documentation technic for collecting data. Online learning used online-based platforms and applications, namely Microsoft Teams. Teachers conduct virtual meetings to deliver material by using Youtube and Whatsapp application to strengthen student's understanding, to give assignments, and to do assessments. As a result, this study found some learning obstacles: (1) a few of students can use cellphones independently,(2) parents are not able to accompany student well, (3) unsupportive internet network, and (4) limited time in online learning so that teachers have difficulty monitoring student attitudes when studying at home. Strategic steps taken by the school include (a) increasing the capacity of teachers in mastering digital technology, $(b)$ using online learning media that is more 
varied and interactive, (c) delivering material to students the day before, and (d) involving parents of students intensively in helping and accompanying student learning. Keywords: online learning, the covid-19 pandemic, elementary school

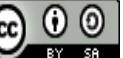

This work is licensed under a Creative Commons Attribution-ShareAlike 4.0 International License. Allows readers to read, download, copy, distribute, print, search, or link to the full texts of its articles and allow readers to use them for any other lawful purpose.

Copyright (c) 2021 Bagus Cahyanto, Masyinta Maghfirah, dan Nur Hamidah Received 09 Mei 2021, Accepted 20 Mei 2021, Published 26 Mei 2021

\section{A. Pendahuluan}

Pandemi Covid-19 yang melanda Indonesia belakangan ini telah membawa dampak besar terhadap praktik pembelajaran di berbagai level pendidikan mulai tingkat dasar hingga pendidikan tinggi. Hal ini membuat seluruh elemen pendidikan harus menyusun sebuah strategi di tengah keterbatasan yang ada saat ini untuk memastikan keberlangsungan pembelajaran dapat berjalan dengan baik. Pembelajaran daring (dalam jaringan) menjadi sebuah alternatif solusi dalam upaya mencegah penyebaran virus Covid-19 di lingkungan sekolah formal untuk meminimalkan interaksi sosial secara berlebihan. Pembelajaran di sekolah yang semula dilaksanakan tatap muka secara langsung di ruang kelas offline kini telah beralih menjadi pembelajaran yang dilaksanakan secara online dan memungkinkan belajar tanpa batasan ruang dan waktu. Sistem pembelajaran daring ini merupakan sistem yang memungkinkan pembelajaran dapat dilaksanakan jarak jauh antara guru dan siswa melalui jaringan internet. Meskipun siswa dan guru berada di tempat yang berbeda pembelajaran tetap dapat dilaksanakan, sehingga interaksi pengajar dan siswa dilakukan melalui jaringan komunikasi elektronik dengan desain pembelajaran online (Moawad, 2020; Nicol, Minty, \& Sinclair, 2003).

Kemendikbud melalui Surat Edaran Nomor 15 Tahun 2020 tentang pedoman penyelenggaraan belajar dari rumah dalam masa darurat penyebaran Covid-19 memberlakukan regulasi untuk pemenuhan hak siswa untuk mendapatkan layanan pendidikan selama pandemi Covid-19. Hal ini bertujuan untuk melindungi warga satuan pendidikan dari dampak buruk Covid-19, mencegah penyebaran dan penularan Covid19 di satuan pendidikan serta memastikan pemenuhan dukungan psikososial bagi guru, siswa, dan orang tua. Pembelajaran daring ini pada dasarnya merupakan bentuk pembelajaran yang dilakukan dengan bantuan jaringan internet yang secara teknis dibantu dengan menggunakan beberapa alat perantara seperti laptop, komputer, gadget (smartphone), dan media lainnya. Pembelajaran daring merupakan bagian dari solusi mengatasi learning poverty di sekolah (Sadikin \& Hamidah, 2020). Lembaga pendidikan dapat menggunakan platform pendukung untuk memudahkan pembelajaran yang dilaksanakan guru dan siswa, sehingga walaupun pembelajaran dilaksanakan secara online diharapkan tidak mengurangi penguasaan kompetensi yang harus dicapai oleh siswa (Kidd \& Murray, 2020). 
Pada level pendidikan dasar, pelaksanaan pembelajaran daring perlu bimbingan guru dan orang tua dalam menumbuhkan kesadaran dan kemandirian belajar siswa. Artinya keberhasilan pembelajaran daring di level pendidikan dasar ini sangat dipengaruhi oleh banyak faktor diantaranya kesiapan guru, siswa, dan orang tua dalam mendampingi siswa belajar secara online. Guru perlu mempersiapkan sejumlah perangkat pembelajaran yang dapat memfasilitasi siswa untuk belajar mandiri, hal ini dapat juga dilakukan dengan memanfaatkan beberapa aplikasi yang banyak tersedia seperti Zoom Meeting, Google Classroom, Edmodo, Google Meet, Moodle, Whatsapp, Schology, dan platform lainnya. Selain itu guru juga perlu menjelaskan harapan serta tujuan dan kriteria penilaian kepada siswa untuk mengatasi tantangan belajarnya (Kearns, 2012; Leary, 2019; Youngblood, Trede, \& Di Corpo, 2001). Disisi lain siswa juga harus memiliki kesadaran dan kemandirian belajar di tengah pembelajaran daring yang membuat guru kesulitan memantau perkembangan belajar siswa secara langsung. Siswa yang belajar dari rumah tentu juga membutuhkan bantuan orang tua dalam proses pendampingan belajar serta memastikan bahwa siswa dapat berpartisipasi dengan baik dalam pengalaman-pengalaman belajar yang dilaksanakan secara online.

Pembelajaran dengan bantuan media elektronik (e-learning) menjadi bagian yang tidak dapat dipisahkan di masa pandemi Covid-19. Bahan ajar berbasis multimedia saat ini sangat membantu pelaksanaan pembelajaran jarak jauh, hal ini dapat mengintegrasikan dan menyajikan materi pembelajaran dalam berbagai media seperti gambar, teks, video, dan suara (Akrim, 2018; Zhang, Zhao, Zhou, \& Nunamaker, 2004). Kelebihan pembelajaran melalui media online ini juga diiringi dengan tantangan bagi penggunanya, sehingga menjadi bagian yang menarik untuk diungkap sebagai bahan evaluasi dan perbaikan agar pembelajaran menjadi lebih baik. Pembelajaran daring dan lingkungan belajar yang menarik memiliki peran yang signifikan dalam pengembangan akademik dan prestasi siswa dalam pembelajaran (Ibem, Alagbe, \& Owoseni, 2017). Selain itu pengelolaan pembelajaran dan pengelolaan kelas yang tepat akan berdampak pada proses sosial dan menumbuhkan suasana belajar yang menggairahkan (Cahyanto, Akbar, \& Sa, 2018; Popyk, 2021).

Sekolah Dasar Brawijaya Smart School Malang atau sering dikenal dengan SD BSS merupakan salah satu sekolah yang menerapkan sistem pembelajaran daring saat pandemi Covid-19 di kota Malang. Sejak diumumkannya regulasi belajar dari rumah (BDR) SD Brawijaya Smart School melaksanakan pembelajaran menggunakan beberapa platform pembelajaran online. Pada pembelajaran daring siswa dan guru dapat melaksanakan pembelajaran jarak jauh serta berkomunikasi secara virtual. Hal ini tentu membutuhkan perangkat dan fasilitas dasar yang mendukung, ketersediaan jaringan internet yang stabil, serta kemampuan guru dalam mengelola pembelajaran yang baik, sehingga dengan begitu tujuan pembelajaran daring dalam menjangkau banyak siswa akan tercapai (Adlani \& Hanifah, 2020). 
Berdasarkan hasil pengamatan pelaksanaan pembelajaran daring di SD Brawijaya Smart School tidak secara tiba-tiba berjalan dengan baik dan lancar. Hasil wawancara dengan guru kelas menunjukkan bahwa pembelajaran daring di kelas III masih menemui beberapa kendala, walaupun secara teknis upaya sekolah terus dilakukan untuk meningkatkan kemampuan guru dalam penyelenggaraan pembelajaran online. Secara umum pembelajaran daring memiliki support system yang berbeda dengan pembelajaran di ruang kelas, virtual class ini memberikan peluang besar kepada siswa untuk belajar secara mandiri walaupun tanpa kehadiran seorang pendidik atau guru secara langsung dalam tatap muka (Cahyanto \& Afifulloh, 2020). Pemanfaatan media video, metode dan model yang variatif dapat dilakukan untuk menumbuhkan kemenarikan pembelajaran daring.

Berdasarkan hasil wawancara dengan guru menunjukkan bahwa pembelajaran daring belum sepenuhnya menjadi alternatif yang sempurna, sistem yang serba online ini tentu memiliki kelebihan pada beberapa aspek dan diiringi kekurangan pada aspek lain. Untuk mengetahui ini semua maka perlu dilakukan penggalian informasi berkaitan dengan pelaksanaan pembelajaran daring di sekolah. Dinamika dan perkembangan pembelajaran daring perlu diungkap lebih jauh untuk mengetahui kendala apa saja yang muncul dalam praktik pembelajaran daring di satuan pendidikan. Berdasarkan uraian diatas maka peneliti memiliki ketertarikan untuk mengungkap informasi yang berkaitan dengan pelaksanaan pembelajaran daring selama pandemi Covid-19, kendala yang muncul serta langkah strategis yang dilakukan untuk mengatasi kendala pembelajaran daring di SD Brawijaya Smart School.

\section{B. Metode}

Penelitian ini bertujuan untuk mendeskripsikan tentang pelaksanaan pembelajaran daring di SD Brawijaya Smart School, kendala-kendala yang muncul dan langkah strategis yang sudah dilakukan sekolah untuk mengatasi kendala tersebut. Penelitian ini akan menggali pengalaman dan pemaknaan guru dalam pembelajaran daring selama masa pandemi Covid-19. Pendekatan pada penelitian ini menggunakan pendekatan kualitatif deskriptif, hal ini disesuaikan dengan tujuan penelitian yang ingin mengekplorasi dan mendeskripsikan sebuah kondisi alami yang menekankan pada proses, makna, dan pemahaman berupa kata-kata (Bogdan \& Biklen, 2007; Kusumastuti \& Mustamil, 2019; Nugrahani, 2014) terkait pelaksanaan pembelajaran daring. Guru kelas IIIA SD Brawijaya Smart School dipilih sebagai subjek penelitian dengan teknik pengumpulan data melalui wawancara mendalam, observasi, dan dokumentasi.

Peneliti menggunakan teknik analisa yang meliputi tahap reduksi data, penyajian, verifikasi dan penarikan kesimpulan sebagai upaya mendapatkan data hasil penelitian yang akurat (Miles, Huberman, \& Saldana, 2014). Reduksi data dilakukan dengan menyederhanakan dan melakukan perubahan dari data yang telah diperoleh secara kasar di lapangan, proses ini dilakukan selama penelitian di lapangan hingga data 
benar-benar terkumpul, dilanjutkan dengan penyajian data atau penyusunan informasi, sehingga dapat memberikan kemungkinan dalam penarikan kesimpulan dan pengambilan tindakan dari seorang peneliti, serta penarikan kesimpulan hasil analisis data yang dimana kesimpulan awal yang masih bersifat sementara dan dapat mengalami perubahan jika ditemukan bukti-bukti yang kuat untuk mendukung pada tahap pengumpulan data berikutnya. Sedangkan untuk mendapatkan keabsahan data penelitian, peneliti menggunakan tekhik triangulasi.

\section{Hasil dan Pembahasan}

Pandemi Covid-19 membawa dampak terhadap praktik pembelajaran di sekolah, dimana pelaksanaan pembelajaran dari tatap muka secara offline beralih menuju pembelajaran online. Adanya Peraturan Menteri Pendidikan dan Kebudayaan Republik Indonesia terkait Surat Edaran tentang Pembelajaran secara daring dan bekerja dari rumah untuk mencegah penyebaran Covid-19, maka seluruh satuan pendidikan dihimbau untuk melaksanakan pembelajaran secara online. Penelitian ini akan mengungkap pelaksanaan pembelajaran daring, kendala-kendala yang muncul dan langkah strategis sekolah untuk mengatasi kendala tersebut. Berdasarkan data hasil wawancara, observasi, dan dokumentasi yang dilakukan peneliti didapatkan data penelitian sebagai berikut.

\section{Pelaksanaan Pembelajaran Daring di Masa Pandemi Covid-19}

Pembelajaran daring memiliki banyak perbedaan dengan metode pembelajaran yang dilakukan secara tatap muka. Pada praktik pembelajaran daring, guru lebih banyak memanfaatkan beberapa platform atau aplikasi pembelajaran berbasis online serta banyak memanfaatkan jaringan internet. Hasil pengamatan dan wawancara peneliti dengan guru menunjukkan bahwa penyelenggaraan pembelajaran daring yang ada di kelas III dilaksanakan dengan memanfaatkan Microsoft Teams. Microsoft Teams merupakan salah satu platform komunikasi yang dapat menggabungkan beberapa fitur seperti percakapan, penyimpanan berkas, dan video conference. Sebelum menentukan penggunaan program tersebut guru telah melakukan koordinasi dengan pimpinan dan seluruh stakeholder yang terkait. Pihak sekolah juga mengadakan pelatihan dasar untuk penggunaan aplikasi ini agar mudah dimengerti baik guru maupun siswa.

Persiapan pembelajaran dimulai dengan melakukan penyusunan perangkat pembelajaran dan seluruh dokumen pendukung. Diawal semester guru terbentuk dalam tim yang telah disesuaikan dengan kelas dan materi yang akan diajarkan. Kegiatan ini merupakan bagian dari perencanaan pembelajaran yang didalamnya terdapat aktivitas pembuatan perangkat pembelajaran, media, bahan ajar, serta berbagai instrumen penugasan dan penilaian yang nantinya akan diberikan kepada siswa saat pembelajaran online. Persiapan pembelajaran yang baik diharapkan dapat memberikan dampak positif terhadap hasil belajar siswa saat pembelajaran online (Sugiri \& Priatmoko, 2020). Pada 
topik-topik tertentu guru juga memanfaatkan aplikasi lain untuk pemberian tugas yang biasa dikirimkan melalui whatsapp group. Guru juga sering menanyakan tentang koneksi internet yang ada dirumah siswa secara berkala, karena hal ini sering menjadi kendala teknis dalam pembelajaran daring. Hal tersebut sesuai dengan pernyataan Anugrahana (2020) bahwa seorang pendidik perlu memastikan jaringan internet siswa dalam kondisi baik sebelum pembelajaran, karena internet yang stabil menjadi salah satu faktor penentu keberhasilan pembelajaran daring di sekolah.

Selain itu, pembelajaran daring di kelas III SD Brawijaya Smart School pada bahasan tema tertentu guru memberikan penugasan untuk melakukan praktik mandiri dari rumah dengan mengirimkan bukti dokumentasi kegiatan berupa foto atau video kepada guru. Di awal guru biasa melakukan penjelasan materi melalui video streaming dengan Microsoft Teams, hal tersebut dilakukan karena ada beberapa materi dalam pembelajaran yang harus dijelaskan secara synchronous. Sebelumnya guru memilih materi yang perlu dilakukan pertemuan secara sinkron maya dan dilakukan dengan asyncrounus. Guru mengatur jadwal jauh-jauh hari sesuai waktu yang telah ditentukan dalam Microsoft Teams untuk diinformasikan melalui whatsapp gruop wali siswa. Hal ini sesuai pandangan Milrad (2013) bahwa untuk mengembangkan lingkungan belajar yang interaktif serta mendorong siswa untuk belajar mandiri guru dapat mengkolaborasikan beberapa platform dan aplikasi untuk keperluan pembelajaran di sekolah. Pelaksanaan pembelajaran menggunakan Microsoft Teams dapat dilihat pada gambar 1 berikut.

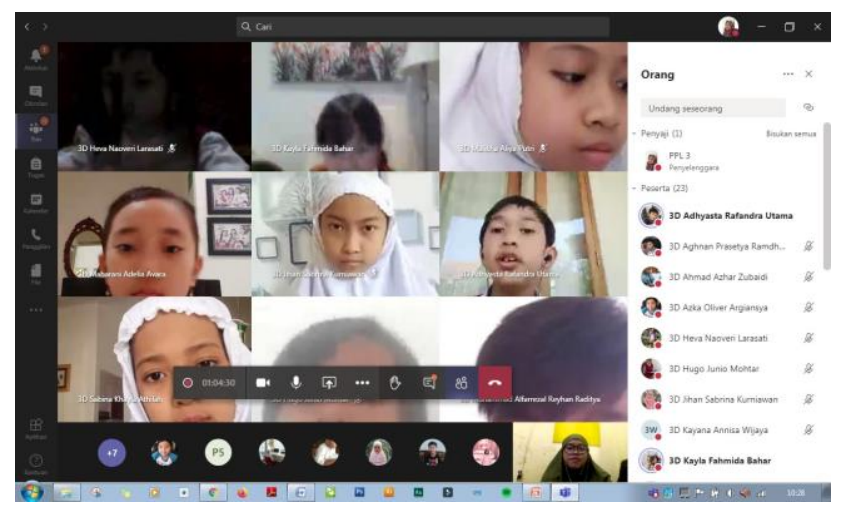

Gambar 1. Kegiatan virtual meeting di awal pembelajaran

Pada saat virtual meeting guru menerapkan beberapa peraturan kepada siswa dalam pembelajaran daring. Hal ini bertujuan untuk mengurangi kemungkinan munculnya gangguan belajar, sehingga siswa dan guru mampu membangun suasana pembelajaran jarak jauh yang efektif. Streaming pada Microsoft Teams diadakan secara berkala untuk memberikan kenyamanan belajar siswa dan memberikan kesempatan kepada siswa untuk mengerjakan tugas dengan bimbingan orang tua dari rumah. Untuk penugasan terdapat fitur tersendiri dalam Microsoft Teams, guru memasukkan 
penugasan serta memberikan batasan pengumpulan tugas. Saat siswa mengumpulkan tugas dan saat penugasan atau pengumpulan siswa langsung mengetahui adanya pemberitahuan tugas dalam aplikasi dan guru dapat langsung mengkoreksi jawaban siswa melalui aplikasi tersebut. Hal ini sesuai pernyataan Rosali (2020) yang menyatakan bahwa pemberian deadline penugasan dalam pembelajaran daring dapat menumbuhkan sikap disiplin pada diri siswa. Artinya guru telah menggunakan berbagai metode dan platform yang beragam dalam pembelajaran daring, hal ini juga didukung pandangan Kristina dkk. (2020) yang menjelaskan bahwa untuk menumbuhkan motivasi belajar siswa guru dapat memanfaatkan berbagai aplikasi berbasis online dalam pembelajaran sehari-hari. Selain itu guru juga memberikan dongeng untuk menumbuhkan semangat belajar serta mengurangi kebosanan belajar seperti yang terlihat pada gambar 2 berikut.

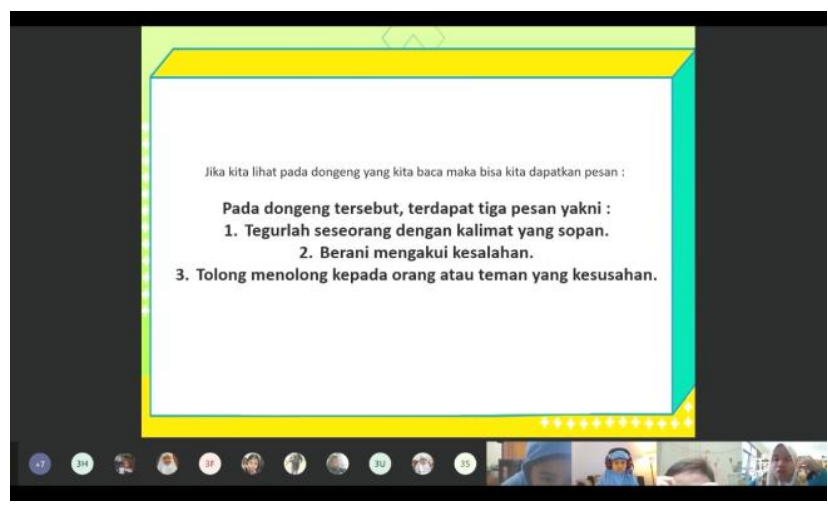

Gambar 2. Pemberian dongeng oleh guru saat pembelajaran

Secara umum praktik pembelajaran daring menuntut guru untuk lebih kreatif dan inovatif dalam mengembangkan pembelajaran daring. Dalam konteks ini guru tidak hanya dituntut untuk memahami materi dengan baik namun juga menyampaikan meteri dengan baik secara online. Hal ini tentu akan menjadikan munculnya beberapa kendala bagi beberapa guru karena tidak semua guru memiliki pemahaman yang sama terhadap aplikasi berbasis online.

\section{Kendala-kendala dalam Pembelajaran Daring di Masa Pandemi Covid-19}

Kendala dalam penelitian ini dimaknai sebagai faktor penghambat yang muncul dalam proses pembelajaran online menggunakan Microsoft Teams di SD Brawijaya Smart School. Pada prinsipnya pembelajaran dapat dikatakan berhasil jika penjelasan materi yang disampaikan guru dapat dengan mudah diterima dan dipahami oleh siswa, sehingga akan tercipta pembelajaran yang aman, nyaman, dan menyenangkan. Hal ini diharapkan agar tujuan pembelajaran dapat tercapai dengan baik. Akan tetapi dalam praktiknya masih seringkali ditemukan beberapa hal yang menjadi kendala dalam pembelajaran daring di sekolah. 
Berdasarkan hasil wawancara peneliti dengan guru kelas III menunjukkan bahwa kendala yang sering muncul dalam proses pembelajaran daring, diantaranya (a) tidak semua siswa menggunakan handphone secara mandiri, khususnya di kelas rendah siswa belum dapat mengoperasikan aplikasi online untuk pembelajaran secara mandiri sehingga siswa sering terlambat dan tidak dapat mengikuti seluruh aktifitas pembelajaran dengan baik, (b) masih adanya orang tua yang belum mampu mendampingi siswa dengan maksimal, sehingga guru kesulitan untuk memantau aktivitas dan perkembangan belajar siswa dirumah. Hal ini tentu akan menghambat siswa dalam hal pengumpulan tugas atau tagihan pembelajaran, masih ada sebagian siswa yang megumpulkan tugas terlambat.

Selanjutnya (c) jaringan internet yang kurang stabil, khususnya pada daerahdaerah tertentu yang kekuatan sinyalnya kurang kuat. Hal ini terkadang juga disebabkan oleh provider yang digunakan siswa untuk mengakses internet, sehingga aktifitas pembelajaran akan terganggu khususnya pada aktivitas video conference. Kendala selanjutnya (d) terbatasnya waktu yang digunakan dalam pembelajaran daring melalui Microsoft Teams, hal ini menyebabkan penjelasan guru pada materi-materi tertentu belum berjalan dengan maksimal. Selain itu guru juga kesulitan untuk memantau karakter atau sikap siswa saat pembelajaran dirumah, Taradisa dkk. (2020) menguatkan bahwa dari semua pembelajaran melalui e-learning tidak semua siswa dapat berhasil. Hal ini dikarenakan beberapa faktor seperti lingkungan belajar dan karakterisitik siswa yang berbeda-beda.

\section{Langkah Strategis Sekolah Untuk Mengatasi Kendala Pembelajaran}

Dalam rangka mengatasi kendala-kendala yang muncul pada pembelajaran daring, sekolah telah melakukan beberapa langkah strategis diantaranya (a) peningkatan kapasitas guru terkait penguasaan teknologi digital. SD Brawijaya Smart School terus melakukan upgrade kemampuan guru terkait keterampilan dalam mengembangkan media dan konten pembelajaran untuk meningkatkan pelaksanaan pembelajaran daring selama pandemi Covid-19 dengan mendorong guru untuk memaksimalkan penggunaan Microsoft Teams, (b) penggunaan media pembelajaran daring yang lebih variatif dan interaktif untuk mengurangi kebosanan siswa dalam belajar. Sekolah melakukan pendampingan dalam pengelolaan pembelajaran agar lebih menarik dan menyenangkan dengan menggunakan media-media yang dapat mendukung pembelajaran online, baik berupa video pembelajaran maupun melalui streaming secara langsung dengan platform yang sudah disediakan sekolah. Selanjutnya (c) mengupayakan materi yang akan disampaikan kepada siswa dalam pembelajaran sehari sebelumnya, materi ini diberikan kepada siswa melalui aplikasi berbasis online yang digunakan guru, serta (d) melibatkan orang tua siswa secara intensif dalam komunikasi dan koordinasi untuk membantu mengawasi dan mendampingi belajar siswa. Hal ini merupakan bagian dari pengotimalan peran tri pusat pendidikan sebagai alternatif solusi dalam memecahkan 
permasalahan pembelajaran daring (Ceka \& Murati, 2016; Herliandry, Nurhasanah, Suban, \& Heru, 2020). Selain itu Sapungan \& Sapungan (2014) juga menjelaskan bahwa peran orang tua sangat penting dalam upaya memaksimalkan perkembangan moral, sikap, dan prestasi akademik siswa di sekolah.

Pada pelaksanaan pembelajaran online tidak lepas dari adanya peran orang tua dalam mengawal proses belajar siswa dari rumah, mengingat usia anak sekolah dasar merupakan usia dimana mereka memerlukan dorongan lingkungan belajar termasuk orang tua dan guru untuk menumbuhkan kemandirian belajarnya. Adanya pembelajaran daring melalui Microsoft Teams ini sekolah berharap dapat memastikan bahwa pembelajaran dapat tetap berjalan ditengah keterbatasan yang ada. Selain itu dalam rangka memantau proses belajar siswa, sekolah juga telah melakukan komunikasi secara berkala dengan orang tua siswa. Hal ini bertujuan untuk memberikan pemahaman sekaligus menjadi bagian dari pengoptimalan peran orang tua untuk meningkatkan prestasi belajar siswa dari rumah, sehingga dukungan dan kerjasama antara sekolah, guru, dan orang tua siswa dalam mendampingi anak belajar di rumah dapat mendukung keberhasilan pembelajaran daring di sekolah.

\section{Simpulan}

Berdasarkan hasil penelitian yang dilaksanakan di SD Brawijaya Smart School tentang pelaksanaan pembelajaran daring selama masa pandemi Covid-19, dapat disimpulkan bahwa pembelajaran daring di kelas III dilaksanakan dengan memanfaatkan beberapa platform atau aplikasi pembelajaran berbasis online yaitu Microsoft Teams. Pada topik dan momen tertentu guru juga memanfaatkan Youtube dan Whatsapp untuk memberikan penguatan materi, penugasan, dan penilaian. Pembelajaran di awali dengan penyusunan perangkat pembelajaran dan seluruh dokumen pendukung melalui tim guru yang sudah dibentuk seperti perangkat pembelajaran, media, bahan ajar, serta berbagai instrumen penugasan dan penilaian yang nantinya akan diberikan kepada siswa saat pembelajaran daring. Guru melakukan kegiatan virtual meeting untuk menyampaikan materi kepada siswa. Selain itu memanfaatkan Youtube dan media layanan pesan (whatsapp) untuk penguatan pemahaman, penugasan, dan penilaian. Pada bahasan tema tertentu guru memberikan penugasan untuk melakukan praktik mandiri dari rumah dengan mengirimkan bukti dokumentasi kegiatan berupa foto atau video kepada guru.

Selanjutnya berkaitan dengan kendala-kendala yang muncul dalam pembelajaran daring yaitu diantaranya (a) tidak semua siswa menggunakan handphone secara mandiri, khususnya di kelas rendah, (b) masih adanya orang tua yang belum mampu mendampingi siswa dengan maksimal, (c) jaringan internet yang kurang stabil, khususnya pada daerah-daerah tertentu, dan (d) terbatasnya waktu yang digunakan dalam pembelajaran daring melalui Microsoft Teams, yang mengakibatkan guru kesulitan untuk memantau sikap siswa saat belajar dirumah. Sekolah juga telah 
melakukan langkah strategis untuk mengatasi kendala yang ada, diantaranya (a) peningkatan kualitas guru terkait penguasaan teknologi digital, (b) penggunaan media pembelajaran daring yang lebih variatif dan interaktif untuk mengurangi kebosanan siswa dalam belajar, (c) mengupayakan materi yang akan disampaikan kepada siswa dalam pembelajaran sehari sebelumnya yang diberikan kepada siswa melalui aplikasi berbasis online, serta (d) melibatkan orang tua siswa secara intensif untuk komunikasi dan koordinasi dalam upaya membantu mengawasi dan mendampingi belajar siswa di rumah sebagai bagian dari pengoptimalan tri pusat pendidikan.

\section{Daftar Rujukan}

Adlani, N., \& Hanifah, M. (2020). Media Alternatif Whatsapp (WA) Mengatasi Permasalahan Pembelajaran pada Situasi Pendemi Covid 19 di Kelas PGMI Semester IV. At-Thullab : Jurnal Pendidikan Guru Madrasah Ibtidaiyah, 4(2), 93. https://doi.org/10.30736/atl.v4i2.215

Akrim, M. (2018). Media Learning in Digital Era. 231(Amca), 458-460. https://doi.org/10.2991/amca-18.2018.127

Anugrahana, A. (2020). Hambatan, Solusi dan Harapan: Pembelajaran Daring Selama Masa Pandemi Covid-19 Oleh Guru Sekolah Dasar. Scholaria: Jurnal Pendidikan dan Kebudayaan, 10(3), 282-289. https://doi.org/10.24246/j.js.2020.v10.i3.p282289

Bogdan, R. C., \& Biklen, S. K. (2007). Qualitative research for education: an introduction to theories and methods (Fifth Edit). Boston New York San Francisco.

Cahyanto, B., \& Afifulloh, M. (2020). Electronic Module (E-Module) Berbasis Component Display Theory (CDT) Untuk Matakuliah Pembelajaran Terpadu. JINOTEP (Jurnal Inovasi dan Teknologi Pembelajaran): Kajian dan Riset Dalam Teknologi Pembelajaran, 7(1), 49-56. https://doi.org/10.17977/um031v7i12020p049

Cahyanto, B., Akbar, S., \& Sa, C. (2018). Desain Fisik Kelas Berbasis Tema untuk Sekolah Dasar. Pendidikan, 3(2002), 15-20.

Ceka, A., \& Murati, R. (2016). The Role of the Parents in the Education of Children. Psychiatry and Clinical Neurosciences, 6(3), 221-230. https://doi.org/10.1111/j.1440-1819.1952.tb01331.x

Herliandry, L. D., Nurhasanah, Suban, M. E., \& Heru, K. (2020). Transformasi Media Pembelajaran Pada Masa Pandemi Covid-19. Jurnal Teknologi Pendidikan, 22(1), $65-70$.

Ibem, E., Alagbe, O., \& Owoseni, A. (2017). A Study of Students' Perception of the Learning Environment: Case Study of Department of Architecture, Covenant University, Ota Ogun State. (March), 6275-6286.

Kearns, L. (2012). Student Assessment in Online Learning: Challenges and Effective Practices. Jolt.Merlot.Org, 8(3), 198-208. 
Kidd, W., \& Murray, J. (2020). The Covid-19 pandemic and its effects on teacher education in England: how teacher educators moved practicum learning online. European Journal of Teacher Education, 43(4), 542-558. https://doi.org/10.1080/02619768.2020.1820480

Kristina, M., Sari, R. N., \& Nagara, E. S. (2020). Model Pelaksanaan Pembelajaran Daring Pada Masa Pandemi Covid 19 Di Provinsi Lampung. Idaarah: Jurnal Manajemen Pendidikan, 4(2), 200. https://doi.org/10.24252/idaarah.v4i2.16945

Kusumastuti, A., \& Mustamil, A. K. (2019). Metode Penelitian Kualitatif.

Leary, T. (2019). Book review of "Assessment Strategies for Online Learning: Engagement and Authenticity." In Canadian Journal of Higher Education (Vol. 48). https://doi.org/10.7202/1057137ar

Miles, M. B., Huberman, A. M., \& Saldana, J. (2014). Qualitative Data Analysis A Methods Sourcebook (Three Edit). SAGE Publications, Inc.

Milrad, M. (2013). Designing an Interactive Learning Environment to Support Children's Understanding in Complex Domains Designing an Interactive Learning Environment to Support Children's Understanding of Complexity. Thinking, (September 1999), 1-178.

Moawad, R. A. (2020). Online Learning during the COVID- 19 Pandemic and Academic Stress in University Students. Revista Romaneasca pentru Educatie Multidimensionala, 12(1Sup2), 100-107. https://doi.org/10.18662/rrem/12.1sup2/252

Nicol, D. J., Minty, I., \& Sinclair, C. (2003). The social dimensions of online learning. Innovations in Education and Teaching International, 40(3), 270-280. https://doi.org/10.1080/1470329032000103807

Nugrahani, F. (2014). Metode Penelitian Kualitatif dalam Penelitian Pendidikan Bahasa. 1(1), 305.

Popyk, A. (2021). The impact of distance learning on the social practices of schoolchildren during the COVID-19 pandemic: reconstructing values of migrant children in Poland. European Societies, 23(S1), S530-S544. https://doi.org/10.1080/14616696.2020.1831038

Rosali, E. S. (2020). Aktifitas Pembelajaran Daring Pada Masa Pandemi Covid -19 Di. Geography Science Education Journal (GEOSEE), 1(1), 21-30.

Sadikin, A., \& Hamidah, A. (2020). Pembelajaran Daring di Tengah Wabah Covid-19. Biodik, 6(2), 109-119. https://doi.org/10.22437/bio.v6i2.9759

Sapungan, G. M., \& Sapungan, R. M. (2014). Parental Involvement in Child's Education: Importan ce, Barriers and Benefits. Asian Journal of Management Sciences \& Education Vol. 3(2) April 2014, 3(April), 42-48.

Sugiri, W. A., \& Priatmoko, S. (2020). Persprektif Asesmen Autentik Sebagai Alat Evaluasi Dalam Merdeka Belajar. At-Thullab : Jurnal Pendidikan Guru Madrasah Ibtidaiyah, 4(1), 53. https://doi.org/10.30736/atl.v4i1.119 
Taradisa, N., Jarmita, N., \& Emalfida. (2020). Kendala Yang Dihadapi Guru Mengajar Daring Pada Masa Pandemi COvid 19 MIN 5 Banda Aceh. UIN Ar-Raniry Banda Aceh, 1(1), 23.

Youngblood, P., Trede, F., \& Di Corpo, S. (2001). Facilitating online learning: A descriptive study. International Journal of Phytoremediation, 22(2), 264-284. https://doi.org/10.1080/0158791010220206

Zhang, D., Zhao, J. L., Zhou, L., \& Nunamaker, J. F. (2004). Can e-learning replace classroom learning? Communications of the ACM, 47(5), 75-79. https://doi.org/10.1145/986213.986216 